\title{
Biosynthetic hydrogen isotopic fractionation factors during lipid synthesis in submerged aquatic macrophytes: Effect of groundwater discharge and salinity
}

Bernhard Aichner (1) https://orcid.org/0000-0002-2471-7466, Sabine Hilt (1) https://orcid.org/0000-0002-0585-2822, Cécile Périllon (1) https://orcid.org/0000-0003-2387-4387, Mikael Gillefalk (1) https://orcid.org/0000-0002-7642-776X, Dirk Sachse 1 https://orcid.org/0000-0003-4207-0309

DOI

10.1016/i.orggeochem.2017.07.021

Original publication date

14 August 2017 (Available online)

Document version

Accepted manuscript

Published in

Organic Geochemistry

\section{Citation}

Aichner B, Hilt S, Périllon C, Gillefalk M, Sachse D. Biosynthetic hydrogen isotopic fractionation factors during lipid synthesis in submerged aquatic macrophytes: Effect of groundwater discharge and salinity. Organic Geochemistry. 2017;113:10-6. 


\section{Biosynthetic hydrogen isotopic fractionation factors during lipid synthesis in submerged aquatic macrophytes: Effect of groundwater discharge and salinity}

Bernhard Aichnera* , Sabine Hiltt, Cécile Périllon ${ }^{b}$, Mikael Gillefalk $^{b}$, Dirk Sachsec

${ }^{a}$ University of Potsdam, Institute of Earth and Environmental Sciences, Potsdam, Germany

${ }^{\mathrm{b}}$ Leibniz-Institute of Freshwater Ecology and Inland Fisheries, Berlin, Germany

' GFZ German Research Centre for Geosciences, Section 5.1: Geomorphology, Organic Surface Geochemistry Lab, Potsdam, Germany

"Corresponding author. E mail address: bernhard.aichner@gmx.de

\section{Highlights}

- Hydrogen isotopic fractionation for Potamogeton grown in a lake and lab measured.

- $\delta$ D values for plants collected from a lake unaffected by groundwater.

- $\delta$ D values of plants grown in the lab became lower at higher salinity.

- Average $\varepsilon$ value $-136 \pm 9 \%$ for freshwater samples 


\begin{abstract}
Sedimentary lipid biomarkers have become widely used tools for reconstructing past climatic and ecological changes due to their ubiquitous occurrence in lake sediments. In particular, the hydrogen isotopic composition (expressed as $\delta \mathrm{D}$ values) of leaf wax lipids derived from terrestrial plants has been a focus of research during the last two decades and the understanding of competing environmental and plant physiological factors influencing the $\delta \mathrm{D}$ values has greatly improved. Comparatively less attention has been paid to lipid biomarkers derived from aquatic plants, although these compounds are abundant in many lacustrine sediments.

We conducted a field and laboratory experiment to study the effect of salinity and groundwater discharge on the isotopic composition of aquatic plant biomarkers. We analyzed samples of the common submerged plant species, Potamogeton pectinatus (sago pondweed), which has a wide geographic distribution and can tolerate high salinity. We tested the effect of groundwater discharge (characterized by more negative $\delta \mathrm{D}$ values relative to lake water) and salinity on the $\delta \mathrm{D}$ values of $n$-alkanes from $P$. pectinatus by comparing plants (i) collected from the oligotrophic freshwater Lake Stechlin (Germany) at shallow littoral depth from locations with and without groundwater discharge, and (ii) plants grown from tubers collected from the eutrophic Lake Müggelsee in nutrient solution at four salinity levels. Isotopically depleted groundwater did not have a significant influence on the $\delta \mathrm{D}$ values of $n$ alkanes in Lake Stechlin $P$. pectinatus and calculated isotopic fractionation factors $\varepsilon_{\mathrm{l} / \mathrm{w}}$ between lake water and $n$-alkanes averaged $-137 \pm 9 \%\left(n-\mathrm{C}_{23}\right),-136 \pm 7 \%\left(n-\mathrm{C}_{25}\right)$ and $-131 \pm 6 \%$ o $\left(n-\mathrm{C}_{27}\right)$, respectively. Similar $\varepsilon$ values were calculated for plants from Lake Müggelsee grown in freshwater nutrient solution ( $-134 \pm 11 \%$ for $n-\mathrm{C}_{23}$ ), while greater fractionation was observed at increased salinity values of 10 (163 $\pm 12 \%$ o) and $15(-172 \pm 15 \%)$.
\end{abstract}

We therefore suggest an average $\varepsilon$ value of $-136 \pm 9 \%$ between source water and the major $n$-alkanes in $P$. pectinatus grown under freshwater conditions. Our results demonstrate that isotopic fractionation can increase by 30-40\%o at salinities 10 and 15. These results could be explained either by inhibited plant growth at higher salinities, or by metabolic adaptions to salt stress that remain to be elucidated. A potential salinity effect on $\delta \mathrm{D}$ values of aquatic lipids requires further examination, since this would impact the interpretation of downcore isotopic data in paleohydrologic studies. 


\section{Introduction}

The hydrogen isotopic composition (expressed as $\delta \mathrm{D}$ values) of leaf wax lipids extracted from sediments is increasingly being used by paleoclimatologists to reconstruct past hydrological conditions (e.g. reviewed by Castaneda and Schouten, 2011; Sachse et al., 2012). These compounds track the hydrogen isotopic signature of ambient water, which is lake water for submerged aquatic plants and soil water for terrestrial vegetation (Sauer et al., 2001; Huang et al., 2004; Sachse et al., 2006), the latter with additional influence from transpiration (Kahmen et al., 2013a, b). Due to deuterium (D) discrimination during lipid synthesis, these compounds are usually $\mathrm{D}$ depleted (more negative $\delta \mathrm{D}$ value) relative to the source water (Sessions et al., 1999; Chikaraishi and Naraoka, 2003; Zhang and Sachs, 2007; Zhang et al., 2009). To reconstruct the isotopic signature of precipitation or lake water it is therefore important to estimate the magnitude of the fractionation factor between leaf wax lipids and source water $(\varepsilon$ l/w or sometimes referred to as the apparent fractionation $\left.\varepsilon_{\mathrm{app}}\right) . \varepsilon_{\mathrm{l} / \mathrm{w}}$ integrates several potentially influencing factors on isotopic fractionation, such as relative humidity, plant physiological differences and biochemical reactions $\left(\varepsilon_{\text {bio }}\right)$ (Sachse et al., 2012). Previous studies have demonstrated that $\varepsilon_{\mathrm{l} / \mathrm{w}}$ has significant inter and intra species variation (reviewed by Sachse et al., 2012). Culturing experiments have further shown that salinity, growth rate, temperature, and irradiance may have an effect upon $\varepsilon_{1 / \mathrm{w}}$ of lipids derived from algae (reviewed by Sachs, 2014; e.g. Schouten et al., 2006; Sachs and Schwab, 2011; 
M’Boule et al., 2014; Chivall et al., 2014; Nelson and Sachs, 2014; Heinzelmann et al., 2015; van der Meer et al., 2015; Maloney et al., 2016).

Aquatic plant lipids are useful for paleohydrological reconstructions because submerged aquatic macrophytes do not use leaf water for lipid biosynthesis as terrestrial plants do. Instead they utilize lake water as a hydrogen source hence directly record the lake water isotopic composition. Despite their ubiquitous occurrence in lake sediments (Ficken et al., 2000; Aichner et al., 2010a, b), the amount of $\varepsilon_{1 / \mathrm{w}}$ data for submerged aquatic plant lipids, such as $n$ - $\mathrm{C}_{23}$ and $n$ - $\mathrm{C}_{25}$ alkanes is low (Chikaraishi and Naraoka, 2003; Mügler et al., 2008; Duan and Xu, 2012; Duan et al., 2014). Some other studies have attempted to estimate $\varepsilon_{1 / \mathrm{w}}$ of aquatic plants from $\delta D$ measurements of sedimentary lipids (e.g. Sachse et al., 2006; Günther et al., 2013). However, sedimentary mid-chain $n$-alkanes, which are commonly attributed to aquatic organisms, are also produced by terrestrial plants, albeit in lower amounts (Aichner et al., 2010a; Gao et al., 2011; Liu et al., 2015). Thus, sedimentary accumulations often constitute mixtures which could bias the estimation of $\varepsilon_{1 / \mathrm{w}}$-values.

Further, the potential impact of environmental factors such as groundwater discharge and salinity on the isotopic signatures of aquatic plant lipids has not been examined. $\delta \mathrm{D}$ values of groundwater could be distinct from lake water $\delta \mathrm{D}$. As such, groundwater discharge into littoral areas potentially affects $\delta \mathrm{D}$ of aquatic plants (Périllon and Hilt, 2016). Aquatic plant lipids are also found in saline lakes, but it is unclear whether or not salinity might exert a control on $\varepsilon 1 / \mathrm{w}$, as has been shown for 
cyanobacteria (Sachse and Sachs, 2008), algae (Schouten et al., 2006; Sachs and Schwab, 2011), and mangroves (Ladd and Sachs, 2012 and 2017). This lack of understanding results in uncertainty when interpreting paleoclimate records, particularly when the aim is to quantitatively reconstruct $\delta \mathrm{D}$ values of source water.

In this study, we analyzed $n$-alkanes from the submerged aquatic angiosperm sago pondweed, Potamogeton pectinatus (also named Stuckenia pectinata) to test if salinity and groundwater discharge influence their $\delta \mathrm{D}$ values. $P$. pectinatus occurs nearly worldwide from sea level to 5,000 m above sea level. It can grow on a variety of bottom substrates and is able to tolerate a wide range of chemical environments (Van Wijk, 1988; Van Wijk et al., 1988; Casey, 2010). To test for the effect of groundwater discharge, we analyzed plants collected from a groundwater-fed freshwater lake at locations with and without groundwater discharge. To examine the effect of salinity, we grew $P$. pectinatus from tubers collected from a eutrophic lake under controlled laboratory conditions in four different salinity treatments.

\section{Material and methods}

\subsection{Samples}

Above ground parts of submerged $P$. pectinatus from the oligo-mesotrophic Lake Stechlin were collected in July 2014 with at least two plants per treatment (Fig. 1; for lake characteristics see Supplementary Table S1). Samples were taken at $50 \mathrm{~cm}$ water depth, at one site without the influence of groundwater discharge (C1), and 
two different sites proximal to groundwater discharge (GW1 and GW2) (Fig. 1). Detailed analysis of groundwater discharge in Lake Stechlin was performed in a previous study (Périllon et al., 2017). Plants were gently freed from periphyton, dried at $60{ }^{\circ} \mathrm{C}$, and homogenized using a Mini Mill (Pulverisette 23; Fritsch, Germany). Lake water was collected at the same location as the plants and interstitial water was sampled $70 \mathrm{~cm}$ below the sediment using a piezometer.

For the laboratory experiment, $P$. pectinatus tubers were collected from sediment at 30-60 $\mathrm{cm}$ water depth at the northern shore of Lake Müggelsee (Germany) on 21 st March 2016. The tubers were instantly planted into $50 \mathrm{ml}$ glass beakers filled with acid-rinsed sea sand (Roth, Germany) containing a phosphorous source $(0.3 \mathrm{mg} \mathrm{P} / \mathrm{g})$. The beakers were placed into 21 glass cylinders filled with artificial lake water (MIIIKS-nutrient solution; Nicklisch, 1999). Different salinity values were achieved by adding $0,5,10,15,20$ and $30 \mathrm{~g} \mathrm{NaCl} / 1$ to the cylinders, with four replicates for each salinity treatment. This resulted in 24 beakers labelled $0 \mathrm{a}-\mathrm{d}$ (salinity 0 ) to 30 a - d (salinity 30). Each beaker was equipped with two tubers ("1" and "2"). Glass cylinders were covered with lids and placed under $12: 12 \mathrm{~h}$ of light (60 to $180 \mu \mathrm{mol}$ photon $/ \mathrm{m}^{2} / \mathrm{s}$ ) delivered from the top with four fluorescent lamps (Biolux ${ }^{\circledR} \mathrm{L}$ $18 \mathrm{~W} / 965$; OSRAM $)$ in a temperature controlled room $\left(20 \pm 2{ }^{\circ} \mathrm{C}\right)$. On $20^{\text {th }}$ April, plants were harvested for lipid biomarker analysis, dried and weighed and cut into small pieces. Dry weights of plant biomass are listed in the Supplementary Table S6. To monitor potential isotopic drift of the source water, water samples were collected from the glass beakers on days 1,17 and 31 of the experiment $\left(22^{\text {nd }}\right.$ March, 
$6^{\text {th }}$ April and 20th April). We also analyzed water samples taken from Lake Müggelsee in January and July 2016 ( $\mathrm{n}=20)$ from different locations (Supplementary Tables S2 and S3) to assess a potential "storage effect" i.e. an isotopic signal stored in the tubers from the last vegetation period.

\subsection{Organic geochemical and water isotope analysis}

Plant samples were extracted into glass vials for $2 \mathrm{~h}$ in an ultrasonic bath filled with dichloromethane (DCM) / methanol (MeOH) (9:1). The $n$-alkane containing fractions of the extracts were purified by using columns containing a silica gel stationary phase which were flushed with hexane as eluent. Compounds were quantified using gas chromatography (GC; Agilent 7890) equipped with flame ionization detection (FID; Agilent 7683B) and a 30 m Restek DB-5 column (30 m, inner diameter 0.25 $\mathrm{mm}$, film thickness $0.25 \mu \mathrm{m})$. 5a-androstane was added to the samples as internal standard prior to column chromatography. For compound specific hydrogen isotopic analysis we used a GC (Thermo Scientific ${ }^{\circledR}$ Trace) with a Restek RTX-5 column (30 $\mathrm{m}$, inner diameter $0.25 \mathrm{~mm}$, film thickness $0.25 \mu \mathrm{m}$ ) and a split-splitless (SSL) injector operated in splitless mode at an evaporation temperature of $60^{\circ} \mathrm{C}$. The GC instrument (temperature program: 2 minutes static at $70^{\circ} \mathrm{C} ; 15^{\circ} \mathrm{C} / \mathrm{min}$ to $150^{\circ} \mathrm{C}$; $5^{\circ} \mathrm{C} / \mathrm{min}$ to $320^{\circ} \mathrm{C} ; 10 \mathrm{~min}$ static time) was connected via an Isolink with a high temperature conversion (HTC) reactor $\left(1420^{\circ} \mathrm{C}\right)$ and a Conflo IV interface to a DeltaVPlus isotope ratio mass spectrometer. Data derived were normalized to the Vienna Standard Mean Ocean Water (VSMOW) hydrogen isotopic scale by 
calibrating values with an external standard containing $15 n$-alkanes (A5-mix with $\mathrm{C}_{16}$ to $\mathrm{C}_{30}$ of known isotopic composition; A. Schimmelmann, Indiana University, Bloomington). The average root mean square error of replicate measurements of the compounds in the standard-mix across the measurement period was $3.96 \%$. To monitor the stability of the $\mathrm{H}_{3}{ }^{+}$factor (Sessions et al., 2001) this correction parameter was determined before and after each sequence and accounted for $1.84 \pm$ $0.05 \mathrm{ppm} / \mathrm{mv}$ over the three days measuring period.

In most cases the two lab grown plants from one beaker were combined to one sample for isotope ratio mass spectrometry (IRMS) analysis. To achieve a sufficient signal (i.e. $>2000 \mathrm{mV}$ ), single measurement was conducted for five samples by way of manually injecting the complete purified sample extract into the GC-IRMSsystem. Duplicate measurements were conducted for all the other samples. Concerning plants from Lake Stechlin, all samples except for one were measured in triplicate.

Water isotopic values were measured using cavity ring down spectroscopy with a Picarro L2140-i and a Picarro L2130-i. Pore water and lake water were filtered $(45 \mu \mathrm{m})$ before the analysis, and contaminations were screened by using the ChemCorrect software. Each sample was measured ten times, but the first three measurements were discarded when calculating mean values to avoid memory effects. The average standard deviation of those seven replicates was $<0.2 \%$. For calibration of data a VSMOW and a SLAP (Standard Light Antarctic Precipitation) standard (both from International Atomic Energy Agency IAEA, Vienna, Austria; 
each measured 13x) were used. Additionally, 10 measurements of tap water served as a control to monitor drift.

The isotopic fractionation (or apparent enrichment factor) between $\delta \mathrm{D}$ values of lipid compounds and those of water were calculated as follows: $\varepsilon 1 / \mathrm{w}=1000 \mathrm{x}\left[\left(\delta \mathrm{D}_{\text {lipid }}+\right.\right.$ $\left.1000) /\left(\delta \mathrm{D}_{\text {water }}+1000\right)-1\right]$. To estimate the average uncertainty of these fractionation factors the following values were included into an error calculation: the average root mean square error of the A5-standard mix (3.96\%), the average standard deviation of duplicate $\delta \mathrm{D}$-analysis of $n$ - $\mathrm{C}_{23}$-alkanes $(5.20 \%$ ), and the standard deviation of measured $\delta \mathrm{D}$-values of water samples taken during the lab experiment $(0.75 \%)$. Based on these parameters, the computed uncertainty for $\varepsilon_{l / w}$ within the lab experiment accounts for $6.58 \%$.

\section{Results and discussion}

\section{1. $\delta D$ values of water samples}

Lake Stechlin interstitial water samples had significantly higher $\delta \mathrm{D}$ values (Fig. 2) at the site without groundwater influence $(\mathrm{C} 1,-28.6 \pm 0.1 \%)$ compared to values at the sites with groundwater discharge GW1 $(-60.6 \pm 0.1 \%)$ and GW2 $(-63.0 \pm 0.2 \%)$ (Supplementary Table S4). Values at $\mathrm{C} 1$ were close to the lakes surface water isotopic signature $(-26.7 \pm 0.3 \%$. Seasonal variation in $\delta \mathrm{D}$ values of the Lake Stechlin surface water is low, most likely because of its large volume and long residence time. Long term measurements from the Leibniz Institute for Freshwater 
Ecology and Inland Fisheries provided a mean lake water $\delta \mathrm{D}$ value of $-25 \%$ (August 2012 to November 2014, from different depths; J. Lewandowski, personal communication), which was in agreement with our measurement. Groundwater $\delta \mathrm{D}$ values obtained in previous studies were ca. -62\% (83 samples from the watershed, September 2013 to 2014; J. Lewandowski, personal communication). These data are similar to our measured values for interstitial water from sites GW1 and GW2, confirming groundwater discharge at these locations.

In the lab experiment, we observed a slight increase in water $\delta \mathrm{D}$ values with increasing salinity on the first and third water sampling day, but overall isotopic variability was small within a range of ca. 2.5\% (Supplementary Fig. S2 and Table S5). Hence, we used the average of $-54.1 \pm 0.8 \%$ as the $\delta \mathrm{D}$ signature of source water for plants and for computing $\varepsilon$ values. Water samples from Lake Müggelsee had $\delta \mathrm{D}$ values of $-52.8 \pm 0.5 \%$ (July 2016; Supplementary Table S2) and $-55.8 \pm 1.3 \%$ o (January 2016; Supplementary Table S3). These data suggest relatively little seasonal change in lake water $\delta \mathrm{D}$ values, despite a wide seasonal variability in precipitation $\delta \mathrm{D}$ values, ranging from $-83 \%$ in winter to $-48 \%$ in summer (Online Isotopes in Precipitation Calculator, Supplementary Fig. S1; Bowen and Revenaugh, 2003). 


\subsection{Lipid $\delta D$ values of plant samples}

The relative abundances of $n$-alkanes from $P$. pectinatus collected in Lake Stechlin were characterised by $n-\mathrm{C}_{25},>n-\mathrm{C}_{27},>n-\mathrm{C}_{23} . n-\mathrm{C}_{29}$ was also abundant in significant concentrations (Supplementary Table S6). This has been observed in earlier studies (e.g. Aichner et al., 2010a) and illustrates that despite the dominance of mid-chain compounds, aquatic macrophytes could potentially contribute to long-chain $n$ alkanes in sediments. Especially in environments with sparse terrestrial vegetation, this is an important factor to consider, as recently shown by the application of compound-specific carbon isotopic analysis to sediment samples from the Tibetan Plateau (Liu et al., 2015). $\delta$ D values of the three major compounds showed considerable variability of $25 \%$ (-146 to $-169 \%$; Fig. 2 and Supplementary Table S7). This illustrates that intraspecies variability of leaf wax $\delta \mathrm{D}$ values can be relatively large, a phenomenon which has also been observed in terrestrial plants (Sachse et al., 2012).

No significant difference was observed between mean $\delta \mathrm{D}$ values for samples from locations with $\left(n-\mathrm{C}_{25}\right.$ : $\left.-160 \%\right)$ and without $\left(n-\mathrm{C}_{25}\right.$ : $\left.-158 \%\right)$ the influence of isotopically depleted groundwater (t-test $\mathrm{p}=0.71$; Fig. 2). As such, groundwater is likely not a major water source for the plants sampled from this lake. Therefore, the plants sampled for our study, which were from the well-mixed littoral of the lake, took up a lake water rather than a groundwater isotopic signal. This is plausible, as many aquatic plants are able to take up and transport water both through their leaves and roots (Pedersen and Sand-Jensen, 1993; Schönherr, 1976; Van Vierssen et al., 1994). 
Consequently, we used lake water $\delta \mathrm{D}$ values to calculate isotopic fractionation factors $\varepsilon$ (see below).

During the lab experiment, all $P$. pectinatus tubers germinated, but subsequent growth differed significantly between salinity treatments, resulting in final shoot lengths between 35 and $2 \mathrm{~cm}$ (Fig. 3a; Supplementary Table S8). Only plants grown in salinities of $0,5,10$, and 15 contained enough material for $\delta \mathrm{D}$ analysis of $n$ alkanes. In contrast to samples from Lake Stechlin, $n$ - $\mathrm{C}_{23}$ was the most abundant $n$ alkane in all samples from plants grown in the lab. $\delta \mathrm{D}$ values for $n$ - $\mathrm{C}_{23}$ ranged from 164 to $-227 \%$ with a tendency to lower values for plants grown at higher salinities (Fig. 3b). A similar trend was observed for $\mathrm{C}_{25}$-alkanes (Supplementary Table S8). It is remarkable that replicates grown in the same salinity plot showed relatively large isotopic variability of up to ca. $35 \%$.

Since the more negative $\delta \mathrm{D}$ values at higher salinity were paralleled by lower plant growth rate (Fig. 3), an increased use of stored compounds could have influenced the measured values. During germination, $P$. pectinatus first use storage carbohydrates from tubers to build up biomass before incorporating new products of the photosynthesis (Van Vierssen et al., 1994). However, this cannot explain the wide isotopic variability in the plant samples, since Lake Müggelsee (where the tubers were collected) showed relatively little variability in lake water $\delta \mathrm{D}$ values throughout the year (ca. -56 to $-53 \%$; Section 3.1 ). These values are also similar to the $\delta \mathrm{D}$ value of tap water - produced by bank filtration from Lake Müggelsee which was used for production of the medium in our experiment. It cannot be ruled 
out that the storage carbohydrates from the tubers were D-depleted relative to the plant biomass. However, this is unlikely since these substances are usually enriched in D compared to alkyl lipids (Schmidt et al., 2003). Incorporation of a slightly more negative winter signal is unlikely due to the short vegetation period of $P$. pectinatus in Lake Müggelsee, which begins around April and ends in August (Hilt et al., 2013).

\subsection{Hydrogen isotopic fractionation of aquatic plant lipids}

Calculated $\varepsilon / / \mathrm{w}^{-v a l u e s}$ were $-137 \pm 9 \%$ (for $n$ - $\mathrm{C}_{23}$ ), $-136 \pm 7 \%$ (for $\left.n-\mathrm{C}_{25}\right)$ and $-131 \pm$ 6\% (for $n-\mathrm{C}_{27}$ ) for $P$. pectinatus from freshwater Lake Stechlin and $-134 \pm 11 \%$ (n$\mathrm{C}_{23}$ ) for plants grown in the lab (Fig. 4b). These values are comparable with reported isotopic fractionation factors of aquatic plants from freshwater lakes Gunma (Japan; Chikaraishi and Naraoka, 2003) and Gannan Gahai (Tibet; Duan et al., 2014), as well as from the saline Lake Qinghai (Duan and Xu, 2012), but slightly higher than average values from three unspecified submerged plants from brackish Lake Nam Co (Mügler et al., 2008; Fig. 4a).

Samples grown at higher salinity in the lab, had $\varepsilon_{1 / \mathrm{w}}$-values ranging from $-116 \%$ (sample 5-d) to -182\% (sample 15-a, Fig. 4b). Average fractionation factors for salinity $10(-163 \pm 12 \%$ ) and salinity $15(-172 \pm 15 \%$ ) were ca. $30-40 \%$ o larger than that at salinity $0(-134 \pm 11 \%)$ and salinity $5(-133 \pm 17 \%$. A similar trend, i.e. greater fractionation at higher salinity, has been observed in mangroves (Ladd and 
Sachs, 2012, 2017). The magnitude of isotopic depletion with increasing salinity is even larger in our dataset (2.6\% per salinity unit; Fig. $3 b)$ compared to the mangrove data (ca. 1\% depletion per salinity unit; Ladd and Sachs, 2012, 2017). In contrast, smaller $\varepsilon$ values for higher salinity were reported in a number of studies of cyanobacterial and algal lipids such as $n$ - $\mathrm{C}_{17}$-alkane, fatty acids, diploptene, sterols and alkenones (e.g. Schouten et al., 2006; Van der Meer et al., 2007; Sachse and Sachs, 2008; Sachs and Schwab, 2011; M’Boule et al., 2014; Chivall et al., 2014; Nelson and Sachs, 2014; Heinzelmann et al., 2015; Maloney et al., 2016).

The exact mechanism behind salinity dependent isotopic fractionation in different organisms has to be elucidated. There are two possible explanations for the observed D-depletion of $n$-alkanes at higher salinities in our data set: (I) The more negative $\delta \mathrm{D}$ values at higher salinities were a consequence of limited plant growth, as shoots just grew $3-5 \mathrm{~cm}$ in plots with salinities 10 and 15 (Fig. 3a). (II) D-depletion at higher salinities was caused by discrimination of the heavier isotope during water uptake or metabolic processes as a response to salt stress. Factors involving leaf transpiration processes, as discussed for mangroves (Ladd and Sachs, 2012; Ladd and Sachs, 2015a, b), can be excluded for submerged plants.

Under hypothesis I the majority of lipids would be synthesized during the early development of shoots, largely relying on substrate $\mathrm{H}$ rather than water $\mathrm{H}$, whereas lipid synthesis ceased later due to growth inhibition under higher salinities. Lipids synthesized with $\mathrm{H}$ from these substrates could potentially be more D-depleted than those which were produced at later stages if either a) D-depleted substrate is used 
during biosynthesis of early leaf wax lipids (as discussed above in section 3.2.) or if b) D discrimination is relatively large during that process and becomes smaller with continuing growth of the plant. We note that we do not have observational evidence for any of these processes and do not know the $\delta \mathrm{D}$ value of the substrate, but similar hypothesis has been put forward to explain observed seasonal differences in $\varepsilon_{\text {bio }}$ for plants: the seagrass Spartina alterniflora has shown seasonal trends within the $\delta \mathrm{D}$ values of its $n$-alkanes, which has been explained by usage of different substrate for synthesis throughout the vegetation period (Sessions, 2006). Similarly, differences in $\varepsilon_{\mathrm{bi}} \mathrm{O}$ of higher terrestrial plants (Salix and Quercus) over the season have been suggested to be the consequence of the use of carbohydrate substrates during the early season (Newberry et al. 2015, Sachse et al. 2015). These carbohydrate substances would be metabolized through the pentose phosphate cycle and therefore result in D-enriched NADPH fed into biosynthetic pathways (compared to photosynthetic NADPH), while our observation would require a strongly D-depleted $\mathrm{H}$-source. It is notable that the concentrations of $n$-alkanes were higher for the here studied plants with limited growth in salinity plots "10" and "15" (20-87 $\mu \mathrm{g} / \mathrm{g}$ d.w. for $\Sigma n$-alkanes compared to fully grown plants in plots "0" and “5” (3-20 $\mu$ g / g. d.w.); (Supplementary Table S6). Accelerated leaf wax synthesis during the early shoot development and incorporation of a higher proportion of a D-depleted source could be an explanation for the more negative $\delta \mathrm{D}$ values of $n$-alkanes.

Evidence against limited plant growth as a driving factor behind the observed Ddepletion at higher salinities comes from three plants grown at salinities 0 and 5 . 
Plants $0-\mathrm{d}-1,5-\mathrm{a}-1$, and 5-a-2 were significantly shorter $(4.5$ to $8.1 \mathrm{~cm})$ than other replicates at lower salinities but their $n$-alkanes do not show more negative $\delta \mathrm{D}$ values (Fig. 3a; Supplementary Table S8 and Fig. S3). The variable lengths of shoots in these plots are likely not influenced by inhibited growth but rather by different sizes of tubers (Spencer, 1987). Overall, there is no significant correlation between plant length and leaf wax $\delta \mathrm{D}$ values in salinity plots " 0 " and " 5 " $\left(\mathrm{R}^{2}=0.22 ; \mathrm{p}=0.2\right)$.

Under hypothesis II the drivers of larger $\varepsilon_{\text {bio }}$ under higher salinities are associated with strategies of the plants to combat salt stress. These include a) downregulation of water permeability of the cell under higher salinities, resulting in isotopically different intra- and extracellular water, or b) metabolic processes which involve hydrogen transport within the $\mathrm{NADP}^{+}$system and the enzymatically driven leaf wax synthesis itself (Sachs and Schwab, 2011; Sachse et al., 2012; Chivall et al., 2014; Heinzelmann et al., 2015). The exact mechanism used by $P$. pectinatus for adaption to higher salinities is unclear (Casagranda and Boudouresque, 2007). Strategies could include a downregulation of the exchange between extra- and intracellular water to avoid osmotic stress. Aquatic plants including Potamogeton sp. have highly permeable cell membranes to enable water exchange (Schönherr, 1976). Increased D-discrimination during restricted water uptake, resulting in more negative $\delta \mathrm{D}$ values of intracellular water, would be a plausible consequence. Another metabolic response, thought to explain the trend towards lower $\delta \mathrm{D}$ values of leaf wax lipids at higher salinities in mangroves, is the formation of osmolytes, also referred to as "compatible solutes" (Ladd and Sachs, 2012). These are compounds, often sugars, 
which are formed in many kinds of organisms to combat intracellular salt stress. It is unclear to what extent this process is relevant for $P$. pectinatus, and which isotopic signature these compounds have. In case these compounds are relatively enriched in D, which is common for carbohydrates (Schmidt et al., 2003) their biosynthesis would lead to more depleted remaining substrate available for lipid synthesis.

\section{Conclusions}

Alkanes from the common submerged plant species $P$. pectinatus which has been grown under freshwater conditions (Lake Stechlin and lab experiment salinity 0; $\mathrm{n}=$ 13) showed $\varepsilon_{l} / \mathrm{w}$-values of $-136 \pm 9 \%$ for $n$ - $\mathrm{C}_{23}$. Isotopic fractionation for plants grown under higher salinities was larger (salinity $10,-163 \pm 12$ and salinity $15,-172 \pm 15$ ) but plants in these plots were clearly inhibited in their growth compared to those at salinities 0 and 5. Even though there are indications that limited plant growth is not the driving factor behind the observed trend, this needs further examination by analyzing $\delta \mathrm{D}$ values of fully developed plants, which have been grown over a broad salinity gradient. Additional experiments are also needed to determine the effect of salinity on isotopic fractionation for other aquatic plant species, for calibration, and to understand the underlying mechanisms behind the measured data. 
The results indicate that salinity changes must be considered as an additional influencing factor when interpreting $\delta \mathrm{D}$ values of aquatic biomarkers in paleoclimatic records from lakes. This includes applications such as using leaf wax $\delta \mathrm{D}$ as a proxy for lake water $\delta \mathrm{D}$, or dual approaches which combine $\delta \mathrm{D}$ of aquatic and terrestrial biomarkers to reconstruct past humidity conditions.

\section{Acknowledgments}

We acknowledge M. Kaniecki for help during setting up the laboratory experiment as well as C. Zorn and O. Rach for measuring water isotopes. Funding was provided by the German Research Foundation, DFG (grant Ai 134/2-1 to BA and research training group Urban Water Interfaces to $M G$ ) and by the Leibniz association (project AQUALINK for $\mathrm{CP}$ ). We thank Mark Peaple, James Collins, and two anonymous referees whose comments lead to significant improvement of the manuscript. 


\section{References}

Aichner, B., Herzschuh, U.,Wilkes, H., 2010a. Influence of aquatic macrophytes on stable carbon isotope signatures of sedimentary organic matter in lakes on the Tibetan Plateau. Organic Geochemistry 41, 706-718.

Aichner, B., Herzschuh, U., Wilkes, H., Vieth, A., Böhner, J., 2010b. $\delta$ D values of $n$-alkanes in Tibetan lake sediments and aquatic macrophytes a surface sediment study and application to a 16 ka record from Lake Koucha. Organic Geochemistry 41, 779-790.

Bowen, G. J., Revenaugh, J. 2003. Interpolating the isotopic composition of modern meteoric precipitation. Water Resources Research 39, 1299.

Casagranda, C., Boudouresque, C.F., 2007. Biomass of Ruppia cirrhosa and Potamogeton pectinatus in a Mediterranean brackish lagoon, Lake Ichkeul, Tunisia. Fundamental and Applied Limnology 168, 243-255.

Casey, P.A., 2010. Plant Fact Sheet for Sago Pondweed (Stuckenia pectinata (L.) Böerner). USDA-Natural Resources Conservation Service, Kansas Plant Materials Center. Manhattan, KS 66502.

Castañeda, I. S., Schouten, S., 2011. A review of molecular organic proxies for examining modern and ancient lacustrine environments. Quaternary Science Reviews 30, 2851-2891.

Chikaraishi, Y., Naraoka, H., 2003. Compound-specific delta D-delta C-13 analyses of $n$-alkanes extracted from terrestrial and aquatic plants. Phytochemistry 63, 361-371.

Chivall, D., M'Boule, D., Sinke-Schoen, D., Sinninghe-Damsté, J., Schouten, S., van der Meer, M.T.J., 2014. The effects of growth phase and salinity on the hydrogen isotopic composition of alkenones produced by coastal haptophyte algae. Geochimica et Cosmochimica Acta 140, 381390.

Duan, Y., Wu, Y., Cao, X., Zhao, Y., Ma, L., 2014. Hydrogen isotope ratios of individual $n$ alkanes in plants from Gannan Gahai Lake (China) and surrounding area. Organic Geochemistry 77, 96-105.

Duan, Y., Xu, L., 2012. Distributions of n-alkanes and their hydrogen isotopic composition in plants from Lake Qinghai (China) and the surrounding area. Applied Geochemistry 27, 806-814.

Ficken, K..J., Li, B., Swain, D.L., Eglinton, G., 2000. An $n$-alkane proxy for the sedimentary input of submerged/floating freshwater aquatic macrophytes. Organic Geochemistry 31, 745-749.

Gao, L., Hou, J., Toney, J., MacDonald, D., Huang, Y., 2011. Mathematical modeling of the aquatic macrophyte inputs of mid-chain n-alkyl lipids to lake sediments: Implications for interpreting compound specific hydrogen isotopic records. Geochimica et Cosmochimica Acta $75,3781-3791$.

Günther, F., Aichner, B., Siegwolf, R., Xu, B.Q., Yao, T., Gleixner, G., 2013. A synthesis of hydrogen isotope variability and its hydrological significance at the Qinghai-Tibetan Plateau. Quaternary International 313-314, 3-16. 
Heinzelmann, S. M., Chivall, D., M'Boule, D., Sinke-Schoen, D., Villanueva, L., Damsté, J. S. S., Schouten, S., Van der Meer, M.T. J, 2015. Comparison of the effect of salinity on the D/H ratio of fatty acids of heterotrophic and photoautotrophic microorganisms. FEMS Microbiology Letters 362

Hilt, S., Köhler, J., Adrian, R., Monaghan, M.T., Sayer, C. D., 2013. Clear, crashing, turbid and back - long-term changes in macrophyte assemblages in a shallow lake. Freshwater Biology 58, 2027-2036.

Huang, Y.S., Shuman, B., Wang, Y., Webb, T., 2004. Hydrogen isotope ratios of individual lipids in lake sediments as novel tracers of climatic and environmental change: a surface sediment test. Journal of Paleolimnology 31, 363-375.

Kahmen, A., Hoffmann, B., Schefuß, E., Arndt, S.K., Cernusak, L.A., West, J.B., Sachse, D., 2013a. Leaf water deuterium enrichment shapes leaf wax $n$-alkane $\delta \mathrm{D}$ values of angiosperm plants II: observational evidence and global implications. Geochimica et Cosmochimica Acta $111,50-63$.

Kahmen, A., Schefuss, E., Sachse, D., 2013b. Leaf water deuterium enrichment shapes leaf wax $n$-alkane $\delta \mathrm{D}$ values of angiosperm plants I: experimental evidence and mechanistic insights. Geochimica et Cosmochimica Acta 111, 39-49.

Ladd, S.N., Sachs, J., 2012. Inverse relationship between salinity and $n$-alkane $\delta \mathrm{D}$ values in the mangrove Avicennia marina. Organic Geochemistry 48, 25-36.

Ladd, S.N., Sachs, J., 2015a. Hydrogen isotope response to changing salinity and rainfall in Australian mangroves. Plant, Cell and Environment 38, 2674-2687.

Ladd, S.N., Sachs, J., 2015b. Influence of salinity on hydrogen isotope fractionation in Rhizophora mangroves from Micronesia. Geochimica et Cosmochimica Acta 168, 206-221.

Ladd, S.N., Sachs, J., 2017. ${ }^{2} \mathrm{H} /{ }^{1} \mathrm{H}$ fractionation in lipids of the mangrove Bruguiera gymnorhiza increases with salinity in marine lakes of Palau. Geochimica et Cosmochimica Acta 204, 300-312.

Liu, W., Yang, H., Wang, H., An, Z., Wang, Z., Leng, Q., 2015. Carbon isotope composition of long chain leaf wax $n$-alkanes in lake sediments: A dual indicator of paleoenvironment in the Qinghai-Tibet Plateau. Organic Geochemistry 83-84, 190-201.

Maloney, A. E, Shinneman, A. L.C, Hemeon, K., Sachs, J. P., 2016. Exploring lipid 2H/1H fractionation mechanisms in response to salinity with continuous cultures of the diatom Thalassiosira pseudonana. Organic Geochemistry 101, 154-165.

M'Boule, D., Chivall, D., Sinke-Schoen, D., Sinninghe Damsté, J.S., Schouten, S., van der Meer, M.T.J., 2014. Salinity dependent hydrogen isotope fractionation in alkenones produced by coastal and open ocean haptophyte algae. Geochimica et Cosmochimica Acta 130, 126-135.

Mügler, I., Sachse, D., Werner, M., Xu, B., Wu, G., Yao, T., Gleixner, G., 2008. Effect of lake evaporation on $\delta \mathrm{D}$ values of lacustrine $n$-alkanes: A comparison of Nam Co (Tibetan Plateau) and Holzmaar (Germany). Organic Geochemistry 39, 711-729.

Nelson, D.B., Sachs, J.P., 2014. The influence of salinity on D/H fractionation in dinosterol and brassicasterol from globally distributed saline and hypersaline lakes. Geochimica et Cosmochimica Acta 133, 325-309. 
Newberry, S. L., Kahmen, A., Dennis, P., Grant, A., 2015. n-Alkane biosynthetic hydrogen isotope fractionation is not constant throughout the growing season in the riparian tree Salix viminalis. Geochimica et Cosmochimica Acta 165, 75-85.

Nicklisch, A., 1999. Competition between the cyanobacterium Limnothrix redekei and some spring species of diatoms under P-limitation. Internationale Revue der gesamten Hydrobiologie 84, 233-241.

Pedersen, O., Sand-Jensen, K., 1993. Water transport in submerged macrophytes. Aquatic Botany 44, 385-406.

Périllon, C., Pöschke, F., Lewandowski, J., Hupfer, M., Hilt, S., 2017. Stimulation of epiphyton growth by lacustrine groundwater discharge to an oligo-mesotrophic hardwater lake. Freshwater Science. In press. doi.org/10.1086/692832

Périllon, C., Hilt, S., 2016. Groundwater influx differentially affects benthic primary producers in lakes. Hydrobiologia 778, 91-103.

Sachs J.P., 2014. Hydrogen Isotope Signatures in the Lipids of Phytoplankton. In: Holland H.D. and Turekian K.K. (eds.) Treatise on Geochemistry, Second Edition, vol. 12, pp. 79-94. Oxford: Elsevier

Sachs, J.P., Schwab, V.F., 2011. Hydrogen isotopes in dinosterol from the Chesapeake Bay estuary. Geochimica et Cosmochimica Acta 75, 444-459.

Sachse, D., Billault, I., Bowen, G.J., Chikaraishi, Y., Dawson, T.E., Feakins, S.J., Freeman, K.H., Magill, C.R., McInerney, F.A., van der Meer, M.T.J., Polissar, P., Robins, R.J., Sachs, J.P., Schmidt, H.-L., Sessions, A.L., White, J.W.C., West, J.B., Kahmen, A., 2012. Molecular paleohydrology: Interpreting the hydrogen-isotopic composition of lipid biomarkers from photosynthesizing organisms. Annual Review of Earth and Planetary Science 40, 221-249.

Sachse, D., Dawson, T.E., Kahmen, A., 2015. Seasonal variation of leaf wax $n$-alkane production and $\delta 2 \mathrm{H}$ values from the evergreen oak tree, Quercus agrifolia. Isotopes in Environmental and Health Studies, 1-19.

Sachse, D., Sachs, J., 2008. Inverse relationship between D/H fractionation in cyanobacterial lipids and salinity in Christmas Island saline ponds. Geochimica et Cosmochimica Acta 72, 793806.

Sachse, D., Radke, J., Gleixner, G., 2006. $\delta$ D values of individual $n$-alkanes from terrestrial plants along a climatic gradient - Implications for the sedimentary biomarker record. Organic Geochemistry 37, 469-483.

Sauer, P.E., Eglinton, T.I., Hayes, J.M., Schimmelmann, A., Sessions, A.L., 2001. Compoundspecific $\mathrm{D} / \mathrm{H}$ ratios of lipid biomarkers from sediments as a proxy for environmental and climatic conditions. Geochimica et Cosmochimica Acta 65, 213-222.

Schmidt, H.L., Werner, R.A., Eisenreich, W., 2003. Systematics of $2 \mathrm{H}$ patterns in natural compounds and its importance for the elucidation of biosynthetic pathways. Phytochemistry Reviews 2, 61-85.

Schönherr, J., 1976. Water permeability of isolated cuticular membranes: The effect of cuticular waxes on diffusion of water. Planta 31, 159-164. 
Schouten, S., Ossebaar, J., Schreiber, K., Kienhuis, M.V.M., Langer, G., Benthien, A., Bijma, J., 2006. The effect of temperature,salinity and growth rate on the stable hydrogen isotopic composition of long chain alkenones produced by Emiliania huxleyi and Gephyrocapsa oceanica. Biogeosciences 3, 113-119.

Sessions, A.L., Burgoyne, T.W., Schimmelmann, A., Hayes, J.M., 1999. Fractionation of hydrogen isotopes in lipid biosynthesis. Organic Geochemistry 30, 1193-1200.

Sessions, A.L., Burgoyne, T.W., Hayes, J.M., 2001. Correction of $\mathrm{H}_{3}$ contributions in hydrogen isotope ratio monitoring mass spectrometry. Analytical Chemistry 73, 192-199.

Sessions, A.L., 2006. Seasonal changes in D/H fractionation accompanying lipid biosynthesis in Spartina alterniflora. Geochimica et Cosmochimica Acta 70, 2153 - 2162.

Spencer, D.F., 1987. Tuber size and planting depth influence growth of Potamogeton pectinatus L. The American Midland Naturalist 118, 77-84.

van der Meer, M.T.J., Baas, M., Rijpstra, W.I.C., Marino, G., Rohling, E., Damsté, J. S. S., Schouten, S., 2007. Hydrogen isotopic compositions of long-chain alkenones record freshwater flooding of the Eastern Mediterranean at the onset of sapropel deposition. Earth and Planetary Science Letters 262, 594-600.

van der Meer, M.T.J., Benthien, A., French, K.L., Epping, E., Zondervan, I., Reichart, G., Bijma, J., Sinninghe Damsté, J.S., Schouten, S., 2015. Large effect of irradiance on hydrogen isotope fractionation of alkenones in Emiliania huxleyi. Geochimica et Cosmochimica Acta 160, 16-24.

Van Vierssen, W., Hootsmans. M.J.M., Vermaat. J.E., 1994. Lake Veluwe. a MacrophyteDominated System under Eutrophication Stress, Geobotany 21. Kluwer Academic Publishers.

Van Wijk, R.J., 1988. Ecological studies on Potamogeton pectinatus L.. I. General characteristics, biomass productions and life cycles under field conditions. Aquatic Botany 31, 211-258.

Van Wijk, R.J., Van Goor, E.M.J., Verkley, J.A.C., 1988. Ecological studies on Potamogeton pectinatus L. II. Autecological characteristics, with emphasis on salt tolerance, intraspecific variation and isoenzyme patterns. Aquatic Botany 32, 239-260.

Zhang, Z., Sachs, J.P., 2007. Hydrogen isotope fractionation in freshwater algae: I. Variations among lipids and species. Organic Geochemistry 38, 582--608.

Zhang, Z., Sachs, J.P., Marchetti, A., 2009. Hydrogen isotope fractionation in freshwater and marine algae: II. Temperature and nitrogen limited growth rate effects. Organic Geochemistry 40, 428-439. 


\section{Figures}
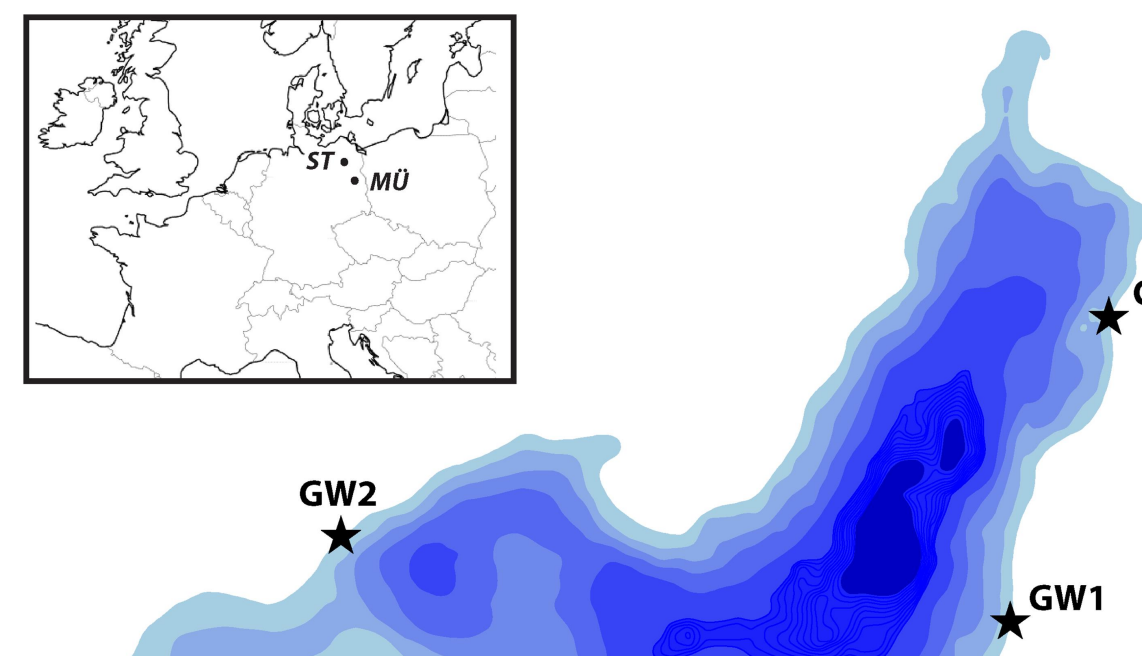

\section{Lake Stechlin}

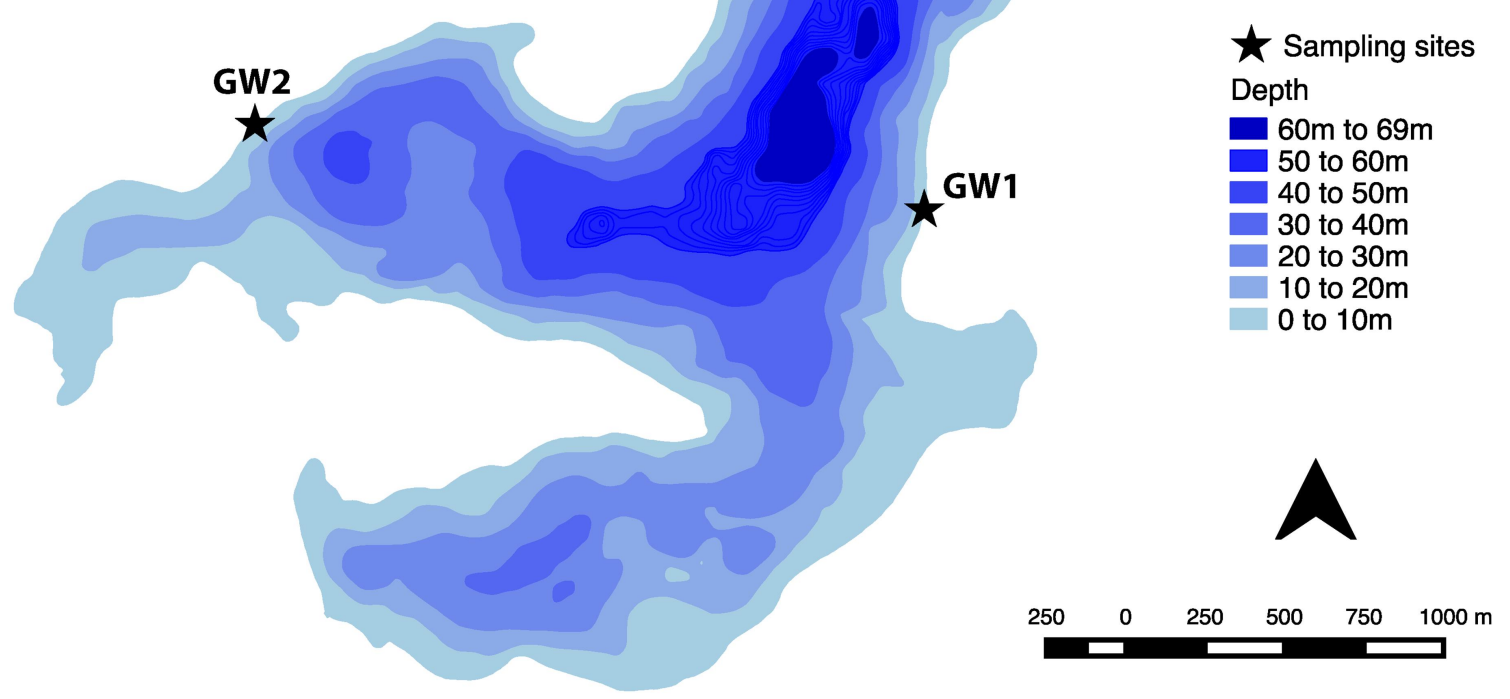

Fig. 1. Locations of lakes Stechlin (ST) and Müggelsee (MÜ). Sampling locations with (GW 1 and 2) and without groundwater discharge (C1) in Lake Stechlin known from detailed analyses by Périllon et al. (2017). 


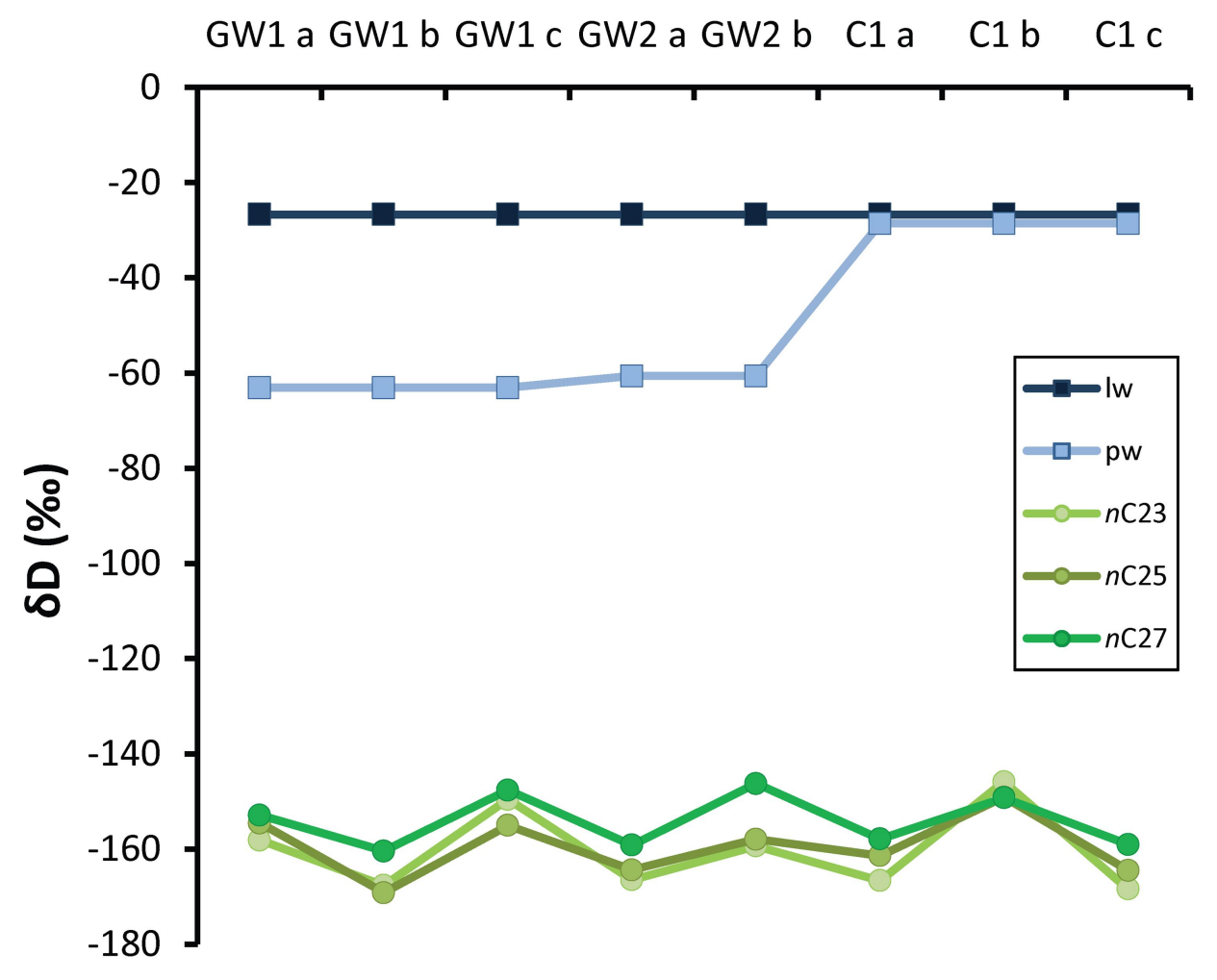

Fig. 2. $\delta \mathrm{D}$ values of lake water (lw), pore water (pw) and $n$-alkanes extracted from macrophytes collected in Lake Stechlin. Standard deviations of replicate measurements were $0.32 \%$ for $\mathrm{lw},<0.2 \%$ for $\mathrm{pw}$ and $1-7 \%$ for $n$-alkanes (Supplementary Tables S4 and S7). 
a)

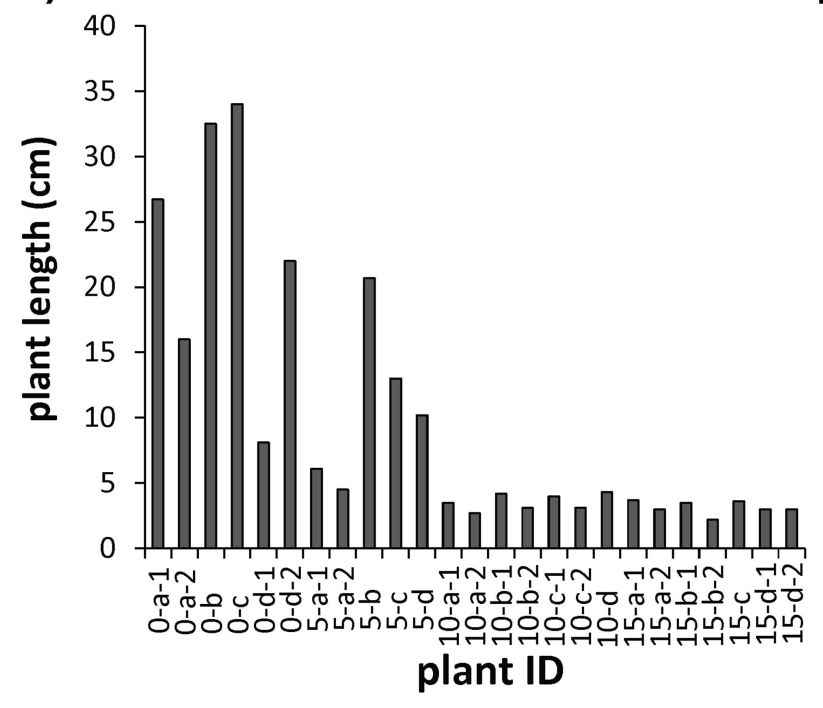

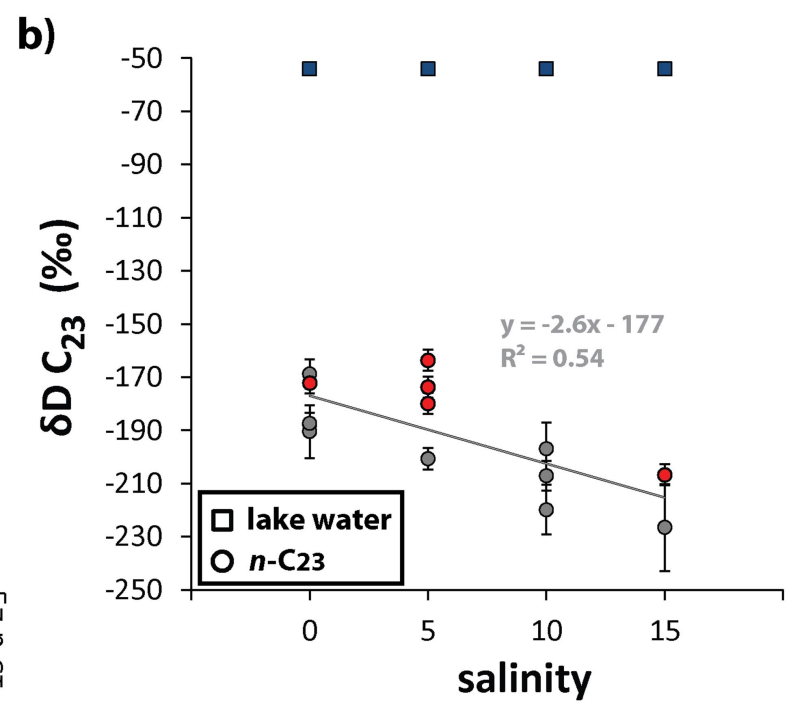

Fig. 3. (a) Length of plants growing in plots with salinity $0,5,10$, and 15 . Plots with salinity 20 and 30 are not shown because plants did not grow at highest salinities. Replicate beakers are labelled a-d. Plants grown in one beaker (labelled 1 and 2) were in some cases combined for IRMS analysis (12) to provide a large enough signal for reliable isotope measurement. (b) Circles indicate $\delta \mathrm{D}$ of $n-\mathrm{C}_{23}$ plotted vs. salinity. Red dots mark samples for which only a single measurement was possible. Error bars combine the standard deviations of duplicate measurements and the root mean square error of the A5-standard-mix (3.96\%). Blue squares indicate $\delta \mathrm{D}$ values of source water (standard deviation: $0.75 \%$ ). 


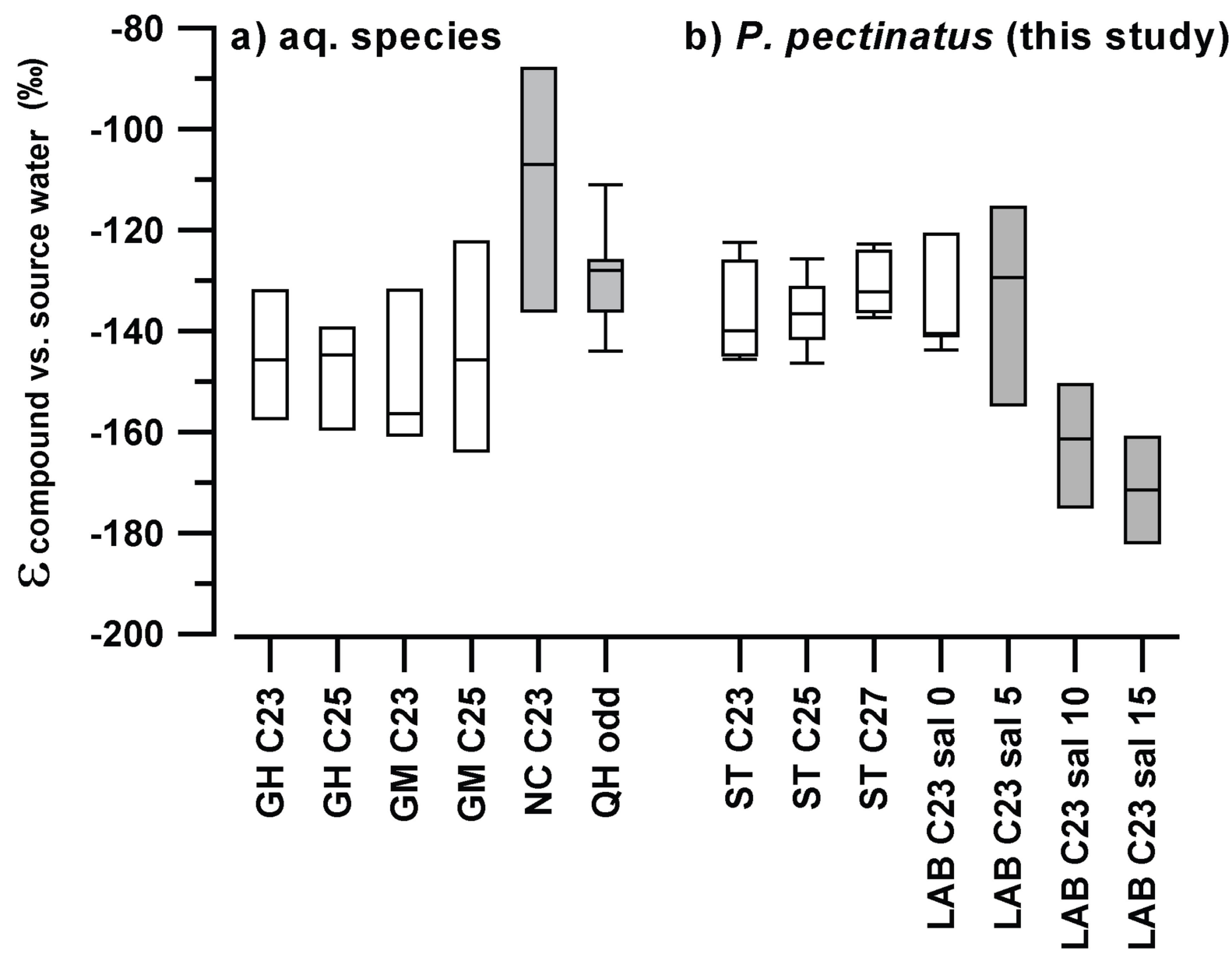

Fig. 4. Isotopic fractionation factor $\varepsilon$ for target compounds vs. source water. (a) Literature data for submerged aquatic species collected at Nam Co (NC; unspecified macrophyte; Mügler et al., 2008), Lake Gahai (GH, Spirogyra intorta, Myriophyllum verticillatum; Duan et al., 2014), Lake Qinghai (QH; Spirogyra intorta, Potamogeton gramineus; Duan and Xu, 2012), and Lake Gunma (GM; Vallisneria asiatica, Potamogeton perfoliatus, Hydrilla verticillata; Chikaraishi and Naraoka, 2003). (b) Results for P. pectinatus (this study) derived from field samples (Lake Stechlin; ST) and lab experiment conducted at different salinity values (SAL 0 - 15). Shaded boxes indicate non-freshwater samples. 


\section{Supplementary material to}

Aichner et al., Organic Geochemistry, 2017 "Biosynthetic hydrogen isotopic fractionation factors during lipid synthesis in submerged aquatic macrophytes: Effect of groundwater discharge and salinity"

https://doi.org/10.1016/i.orggeochem.2017.07.021

Table S1: Lake Stechlin characteristics.

\begin{tabular}{lc}
\hline Location & $53^{\circ} 09^{\prime} \mathrm{N} 13^{\circ} 02^{\prime} \mathrm{E}$ \\
Area $\left(\mathrm{km}^{2}\right)$ & 4.3 \\
Mean/maximum depth $(\mathrm{m})$ & $23 / 69.5$ \\
Water residence time $(\mathrm{yr})$ & $>40$ \\
Conductivity $(\mu \mathrm{S} / \mathrm{cm})$ & $268 \pm 17^{\mathrm{a}}$ \\
Total P concentration $[\mu \mathrm{g} / \mathrm{l}]$ & $14.2 \pm 4.7^{\mathrm{a}}$
\end{tabular}

\footnotetext{
${ }^{a}$ Monthly sampling of surface water, April-September 2013 and 2014. Conductivity measured at plant sampling locations (see Périllon et al. 2017). Total $\mathrm{P}$ determined above deepest point of the lake.
} 
Fig. S1. Seasonal $\delta D$-values of precipitation in our study area. Data from Online Isotope Precipitation Calculator computed forLake Stechlin (Bowen and Revenaugh, 2003).

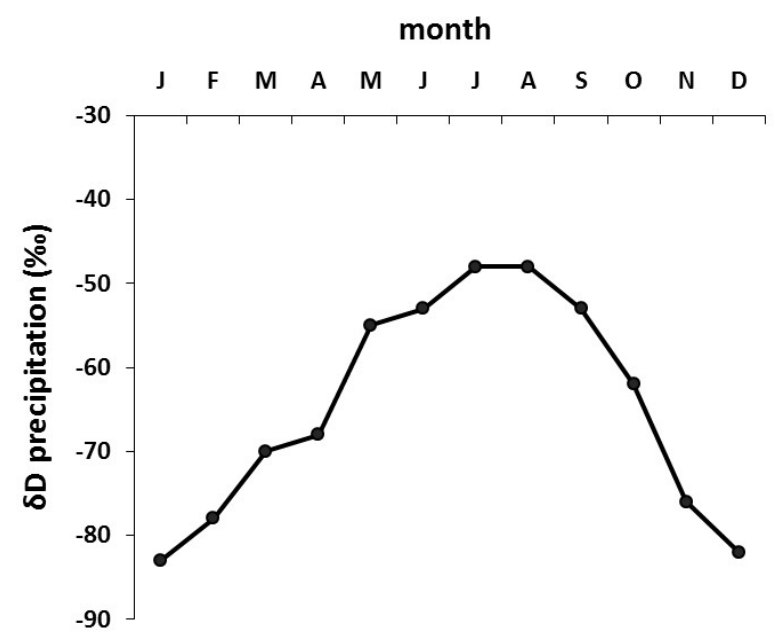

Table S2: $\delta D$-values of water samples from different locations in Lake Müggelsee in July 2016.

\begin{tabular}{cccc} 
Sample & Depth & SD (\%o) & St dev \\
\hline Müggel_1 & shore & -53.87 & 0.36 \\
Müggel_2 & shore & -53.05 & 0.17 \\
Müggel_3 & shore & -52.87 & 0.11 \\
Müggel_4 & $2.7 \mathrm{~m}$ & -52.85 & 0.14 \\
Müggel_5 & $2.7 \mathrm{~m}$ & -52.36 & 0.14 \\
Müggel_6 & $2.7 \mathrm{~m}$ & -52.66 & 0.08 \\
Müggel_7 & shore & -52.68 & 0.06 \\
Müggel_8 & $2.7 \mathrm{~m}$ & -52.61 & 0.10 \\
\hline Avg. & & $\mathbf{- 5 2 . 8 7}$ & \\
St dev & & $\mathbf{0 . 4 5}$ &
\end{tabular}


Table S3: $\delta$ D values of water samples collected at Lake Müggelsee in January 2016 at three locations in ca. $100 \mathrm{~cm}$ depth.

\begin{tabular}{|c|c|c|c|c|}
\hline Sample & $\delta \mathrm{D}(\%)$ & St dev & \multicolumn{2}{|c|}{ Location } \\
\hline 1_1 & -56.3 & 0.10 & $52^{\circ} 26^{\prime} 52.40^{\prime \prime} \mathrm{N}$ & $13^{\circ} 38^{\prime} 54.10^{\prime \prime E}$ \\
\hline 1_2 & -56.5 & 0.15 & & \\
\hline 1_3 & -56.9 & 0.06 & & \\
\hline $1 \_4$ & -56.9 & 0.08 & & \\
\hline 2_1 & -54.7 & 0.09 & $52^{\circ} 26^{\prime} 18.30^{\prime \prime} \mathrm{N}$ & $13^{\circ} 37^{\prime} 17.90^{\prime \prime} \mathrm{E}$ \\
\hline $2 \_2$ & -54.6 & 0.13 & & \\
\hline $2 \_3$ & -54.5 & 0.13 & & \\
\hline $2 \_4$ & -54.3 & 0.07 & & \\
\hline 3_1 & -54.5 & 0.12 & $52^{\circ} 25^{\prime} 46.20^{\prime \prime} \mathrm{N}$ & $13^{\circ} 37^{\prime} 24.60^{\prime \prime E}$ \\
\hline 3_2 & -55.4 & 0.07 & & \\
\hline $3 \_3$ & -56.9 & 0.05 & & \\
\hline $3 \_4$ & -57.9 & 0.05 & & \\
\hline Avg. & -55.8 & & & \\
\hline
\end{tabular}

Table S4: $\delta D$ values of interstitial and lake water sampled in Lake Stechlin. Standard deviation derived from replicate measurements

\begin{tabular}{llcc} 
Sample & Depth & SD (\%o) & St dev \\
\hline Stechlin C1 & $70 \mathrm{~cm}$ below sediment & -28.59 & 0.14 \\
Stechlin GW1 & $70 \mathrm{~cm}$ below sediment & -60.60 & 0.06 \\
Stechlin GW2 & $70 \mathrm{~cm}$ below sediment & -63.04 & 0.16 \\
Stechlin lake water & $50 \mathrm{~cm}$ above sediment & -26.70 & 0.32 \\
\hline
\end{tabular}


Fig. S2. SD-values of water samples taken during the salinity experiment. Error bars indicate standard deviation of replicate measurements. See also Supplementary Table S5.

\section{treatment number}

0-a 0-b 0-c 0-d 5-a 5-b 5-c 5-d 10-a 10-b 10-c 10-d 15-a 15-b 15-c 15-d

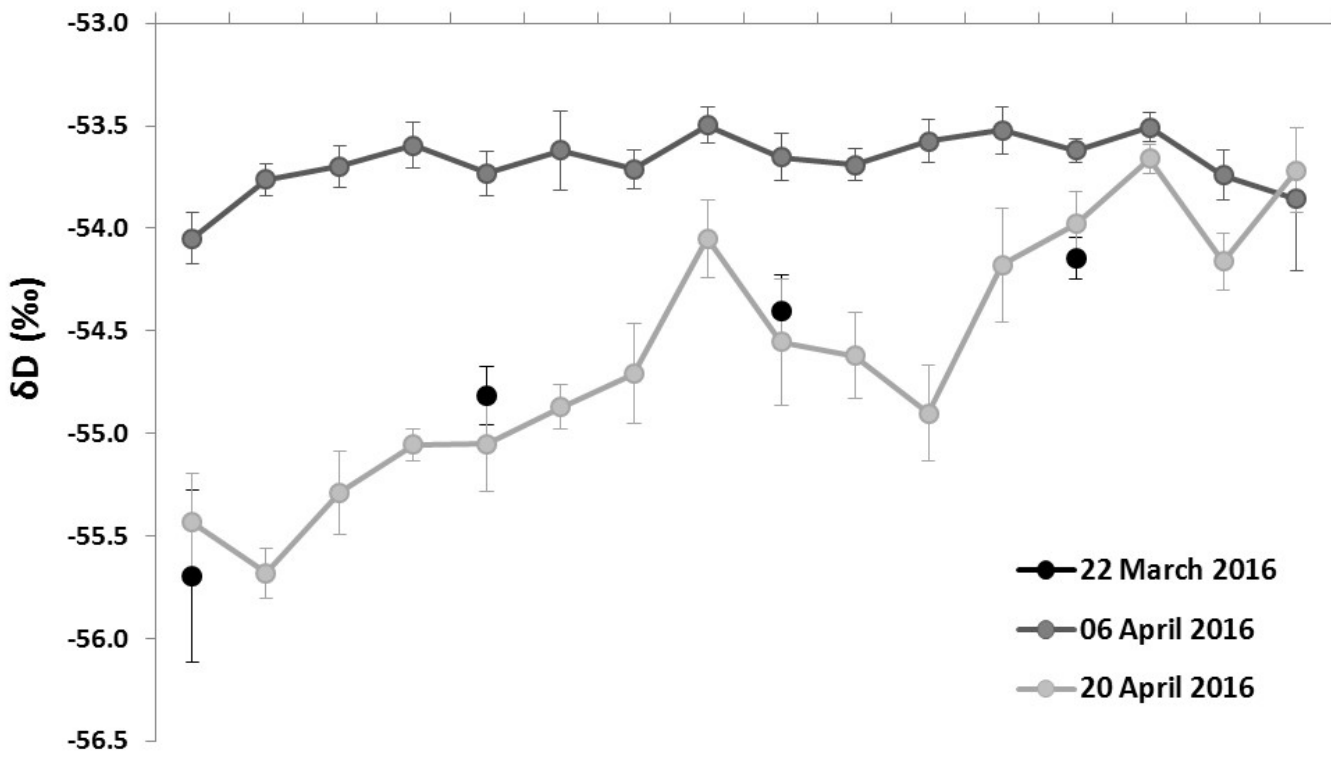


Table S5: $\delta D$-values of water samples taken during the salinity experiment. Data represent average and standard deviation of seven replicate measurements.

\begin{tabular}{|c|c|c|c|c|c|c|}
\hline \multirow[b]{2}{*}{ Sample } & \multicolumn{2}{|c|}{22 Mar 16} & \multicolumn{2}{|c|}{06 Apr 16} & \multicolumn{2}{|c|}{22 Apr 16} \\
\hline & $\delta D[\%]$ & St dev & $\delta D[\%]$ & St dev & $\delta \mathrm{D}[\%$ ] & St dev \\
\hline $0-a$ & -55.70 & 0.42 & -54.05 & 0.12 & -55.43 & 0.24 \\
\hline $0-b$ & & & -53.76 & 0.08 & -55.68 & 0.12 \\
\hline $0-c$ & & & -53.70 & 0.10 & -55.29 & 0.21 \\
\hline $0-d$ & & & -53.59 & 0.11 & -55.06 & 0.08 \\
\hline $5-a$ & -54.82 & 0.14 & -53.73 & 0.11 & -55.05 & 0.23 \\
\hline $5-b$ & & & -53.62 & 0.19 & -54.87 & 0.11 \\
\hline $5-c$ & & & -53.71 & 0.10 & -54.71 & 0.24 \\
\hline $5-d$ & & & -53.50 & 0.09 & -54.05 & 0.19 \\
\hline $10-a$ & -54.40 & 0.18 & -53.65 & 0.12 & -54.56 & 0.31 \\
\hline $10-b$ & & & -53.69 & 0.08 & -54.62 & 0.21 \\
\hline $10-c$ & & & -53.57 & 0.10 & -54.90 & 0.23 \\
\hline $10-d$ & & & -53.52 & 0.12 & -54.18 & 0.28 \\
\hline $15-a$ & -54.15 & 0.10 & -53.62 & 0.06 & -53.98 & 0.16 \\
\hline $15-b$ & & & -53.51 & 0.07 & -53.66 & 0.07 \\
\hline $15-c$ & & & -53.74 & 0.12 & -54.16 & 0.14 \\
\hline $15-d$ & & & -53.86 & 0.35 & -53.72 & 0.21 \\
\hline
\end{tabular}


Table S6: Concentration of $n$-alkanes in P. pectinatus from (a) Lake Stechlin and (b) the lab experiment (d.w., dry weight).

(a)

\begin{tabular}{llccccccccccccc} 
Sample ID & Dry weight $(\mathrm{mg})$ & \multicolumn{1}{c}{ Concentration $(\mu \mathrm{g} / \mathrm{g}$ d.w.) } & \multicolumn{10}{c}{ Abundance [\%] } \\
& & $\mathrm{C}_{21}$ & $\mathrm{C}_{23}$ & $\mathrm{C}_{25}$ & $\mathrm{C}_{27}$ & $\mathrm{C}_{29}$ & $\mathrm{C}_{31}$ & Sum & $\mathrm{C}_{21}$ & $\mathrm{C}_{23}$ & $\mathrm{C}_{25}$ & $\mathrm{C}_{27}$ & $\mathrm{C}_{29}$ & $\mathrm{C}_{31}$ \\
\hline GW1 a & 175 & 0.8 & 5.2 & 6.1 & 6.2 & 3.4 & 1.1 & 22.8 & 3.3 & 22.8 & 27.0 & 27.0 & 15.0 & 4.9 \\
GW1 b & 109 & 3.4 & 10.5 & 16.7 & 15.8 & 8.2 & 2.5 & 57.2 & 6.0 & 18.4 & 29.2 & 27.6 & 14.4 & 4.4 \\
GW1 c & 106 & 0.9 & 4.9 & 8.3 & 7.4 & 4.5 & 1.6 & 27.5 & 3.4 & 17.7 & 30.0 & 26.9 & 16.2 & 5.7 \\
C1 a & 186 & 1.0 & 7.4 & 10.5 & 10.4 & 5.9 & 2.1 & 37.2 & 2.6 & 19.9 & 28.3 & 27.9 & 15.7 & 5.6 \\
C1 b & 198 & 0.7 & 2.0 & 3.4 & 4.8 & 2.6 & 0.9 & 14.4 & 5.2 & 14.2 & 23.7 & 33.0 & 18.0 & 5.9 \\
C1 c & 409 & 1.2 & 10.2 & 13.8 & 12.5 & 6.6 & 2.3 & 46.5 & 2.6 & 21.8 & 29.6 & 26.9 & 14.1 & 5.0 \\
GW2 a & 212 & 15.6 & 15.7 & 21.6 & 23.2 & 14.2 & 6.9 & 97.2 & 16.0 & 16.2 & 22.2 & 23.9 & 14.6 & 7.1 \\
GW2 b & 496 & 1.4 & 1.1 & 1.4 & 1.3 & 1.0 & 0.4 & 6.7 & 15.8 & 18.0 & 22.1 & 21.3 & 15.8 & 7.0 \\
\hline & & & & & & & & Avg. & $\mathbf{6 . 9}$ & $\mathbf{1 8 . 6}$ & $\mathbf{2 6 . 5}$ & $\mathbf{2 6 . 8}$ & $\mathbf{1 5 . 5}$ & $\mathbf{5 . 7}$ \\
& & & & & & & & St dev. & $\mathbf{5 . 7}$ & $\mathbf{2 . 8}$ & $\mathbf{3 . 3}$ & $\mathbf{3 . 4}$ & $\mathbf{1 . 2}$ & $\mathbf{1 . 0}$
\end{tabular}

(b)

\begin{tabular}{llccccccccccccc} 
& & $C_{21}$ & $C_{23}$ & $C_{25}$ & $C_{27}$ & $C_{29}$ & $C_{31}$ & Sum & $C_{21}$ & $C_{23}$ & $C_{25}$ & $C_{27}$ & $C_{29}$ & $C_{31}$ \\
\hline 0-a-12 & 18.6 & 0.6 & 1.1 & 0.6 & 0.5 & 0.3 & 0.3 & 3.0 & 19.0 & 36.6 & 18.5 & 15.2 & 10.6 & 9.7 \\
0-b & 8.4 & 2.7 & 3.3 & 2.1 & 1.5 & 0.8 & 0.6 & 10.3 & 25.8 & 31.6 & 20.7 & 14.3 & 7.5 & 5.4 \\
0-c & 7.4 & 2.7 & 2.0 & 1.3 & 1.1 & 0.6 & 0.6 & 7.8 & 35.1 & 26.2 & 16.5 & 14.4 & 7.8 & 7.2 \\
0-b-1 & 3.3 & 6.5 & 4.3 & 1.9 & 1.2 & 0.6 & 0.0 & 14.6 & 44.9 & 29.3 & 13.1 & 8.3 & 4.4 & 0.0 \\
0-b-2 & 12.5 & 1.6 & 2.9 & 1.5 & 0.8 & 0.5 & 0.5 & 7.4 & 22.2 & 39.6 & 20.5 & 11.3 & 6.4 & 6.5 \\
5-a-12 & 3.2 & 4.1 & 5.8 & 3.9 & 1.9 & 1.0 & 1.0 & 16.6 & 24.3 & 34.7 & 23.4 & 11.3 & 6.2 & 5.9 \\
5-b & 4.7 & 1.7 & 5.0 & 2.5 & 0.9 & 0.7 & 0.4 & 10.7 & 15.9 & 46.3 & 23.2 & 8.5 & 6.1 & 4.2 \\
5-c & 3.3 & 6.8 & 7.1 & 3.4 & 1.9 & 0.7 & 0.5 & 19.9 & 34.3 & 35.4 & 16.9 & 9.6 & 3.8 & 2.3 \\
5-d & 5.0 & 2.9 & 3.6 & 1.6 & 1.0 & 0.4 & 0.3 & 9.5 & 30.6 & 37.3 & 16.6 & 10.8 & 4.7 & 3.0 \\
10-a-12 & 1.4 & 5.9 & 15.6 & 9.6 & 3.0 & 2.1 & 1.2 & 36.3 & 16.4 & 43.1 & 26.5 & 8.4 & 5.7 & 3.2 \\
10-b-12 & 0.6 & 18.3 & 15.9 & 9.1 & 3.6 & 3.3 & 2.3 & 50.1 & 36.4 & 31.7 & 18.2 & 7.1 & 6.6 & 4.7 \\
10-c-12 & 1.1 & 1.6 & 10.8 & 5.4 & 1.3 & 0.8 & 0.9 & 19.9 & 8.2 & 54.0 & 27.0 & 6.6 & 4.2 & 4.3 \\
10-d & 1.7 & 7.0 & 18.8 & 11.2 & 3.0 & 1.8 & 1.2 & 41.8 & 16.7 & 45.0 & 26.9 & 7.2 & 4.3 & 2.8 \\
15-a-12 & 1.5 & 7.0 & 32.5 & 17.7 & 4.9 & 3.0 & 1.5 & 65.1 & 10.7 & 50.0 & 27.2 & 7.5 & 4.7 & 2.3
\end{tabular}




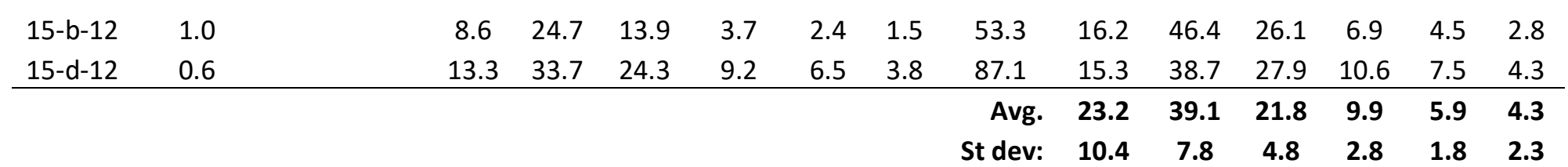

Table S7: $\delta D$-values for Potamogeton pectinatus from Lake Stechlin, as well as $\delta D$ values (\%o) of source water (Iw, lake water; pw, pore water) and isotopic fractionation factor $(\varepsilon)$ of Iw vs. target compounds $n-C_{23}, n-C_{25}$ and $n-C_{27}$ (n.d.., no data; s.m., single measurement; STD, standard deviation of duplicate measurements).

\begin{tabular}{|c|c|c|c|c|c|c|c|c|c|c|c|c|c|c|c|c|}
\hline & $\delta D$ & & $\delta \mathrm{D}$ & & $\delta D$ & & $\delta \mathrm{D}$ & & $\delta D$ & & & & & $\varepsilon$ & & \\
\hline Sample & $\mathrm{C}_{23}$ & STD & $\mathrm{C}_{25}$ & STD & $\mathrm{C}_{27}$ & STD & $\mathrm{C}_{29}$ & STD & $\mathrm{C}_{31}$ & STD & $\delta \mathrm{D}$ lw & $\delta \mathrm{D} p \mathrm{w}$ & $\varepsilon \mathrm{lw} / \mathrm{C}_{23}$ & $\mathrm{Iw} / \mathrm{C}_{25}$ & $\varepsilon \mathrm{lw} / \mathrm{C}_{27}$ & $\varepsilon \mathrm{lw} / \mathrm{C}_{29}$ \\
\hline GW1 a & -158 & 3 & -154 & 3 & -153 & 5 & -145 & 1 & n.d. & s.m. & -26.7 & -63.0 & -135 & -131 & -130 & -122 \\
\hline GW1 b & -168 & 2 & -169 & 1 & -160 & 2 & -136 & s.m. & n.d. & s.m. & -26.7 & -63.0 & -145 & -146 & -137 & -112 \\
\hline GW1 c & -150 & s.m. & -155 & s.m. & -148 & s.m. & -143 & s.m. & n.d. & s.m. & -26.7 & -63.0 & -126 & -132 & -124 & -120 \\
\hline GW2 a & -166 & 7 & -164 & 3 & -159 & 0 & -150 & 2 & -152 & 6 & -26.7 & -60.6 & -144 & -141 & -136 & -127 \\
\hline GW2 b & -159 & s.m. & -158 & 2 & -146 & 4 & -136 & s.m. & n.d. & s.m. & -26.7 & -60.6 & -136 & -135 & -123 & -112 \\
\hline $\mathrm{C} 1 \mathrm{a}$ & -167 & 1 & -161 & 2 & -158 & 1 & -154 & 1 & -151 & 2 & -26.7 & -28.6 & -144 & -138 & -135 & -131 \\
\hline $\mathrm{C} 1 \mathrm{~b}$ & -146 & 1 & -149 & 1 & -149 & 1 & -144 & 0 & n.d. & s.m. & -26.7 & -28.6 & -122 & -126 & -126 & -121 \\
\hline $\mathrm{C} 1 \mathrm{c}$ & -168 & 4 & -164 & 1 & -159 & 2 & -149 & 0 & -142 & 4 & -26.7 & -28.6 & -146 & -142 & -136 & -126 \\
\hline & & & & & & & & & & & & Avg. & -137 & -136 & -131 & -121 \\
\hline
\end{tabular}


Table S8: Plant samples from the lab experiment measured for $\delta \mathrm{D}$-values of $n$-alkanes. Plants grown in one beaker $(1$ and 2$)$ were in some cases combined for IRMS-analysis (12) to gain a strong enough signal for reliable isotope measurement. Standard deviation, (STD) from duplicate

measurements; $\varepsilon$ values calculated vs. a constant $\delta D$ value of water of $-54.1 \%$; $E C$, measured electrical conductivity; s.m., single measurement; n.d., no data.

\begin{tabular}{|c|c|c|c|c|c|c|c|c|c|c|c|c|}
\hline Salinity & $\begin{array}{c}\mathrm{EC} \\
(\mathrm{mS} / \mathrm{cm})\end{array}$ & $\mathrm{pH}$ & Sample & $\begin{array}{c}\text { Plant } \\
\text { length }(\mathrm{cm})\end{array}$ & $\begin{array}{l}\text { Dry weight } \\
\text { (mg) }\end{array}$ & $\begin{array}{c}\text { Sample } \\
\text { IRMS }\end{array}$ & $\begin{array}{c}\delta D C_{23} \\
(\% \circ)\end{array}$ & STD & $\begin{array}{c}\delta D C_{25} \\
(\% \circ) \\
\end{array}$ & STD & $\varepsilon \mathrm{C}_{23}(\% \circ)$ & $\begin{array}{l}\varepsilon \mathrm{C}_{25} \\
(\%)\end{array}$ \\
\hline 0 & 0.6 & 8.4 & $0-a-1$ & 26.7 & 12.7 & $0-a-12$ & -188 & 2 & -175 & s.m. & -141 & -128 \\
\hline 0 & & & $0-a-2$ & 16.0 & 5.9 & & & & & & & \\
\hline 0 & 0.6 & 8.3 & $0-b$ & 32.5 & 8.4 & $0-b$ & -190 & 9 & n.d. & & -144 & \\
\hline 0 & 0.6 & 8.2 & $0-c$ & 34.0 & 7.4 & $0-c$ & -172 & s.m. & n.d. & & -125 & \\
\hline 0 & 0.6 & 8.3 & $0-d-1$ & 8.1 & 3.3 & $0-d-1$ & -169 & 4 & n.d. & & -121 & \\
\hline 0 & & & $0-d-2$ & 22.0 & 12.5 & $0-d-2$ & -187 & 0 & -177 & 0 & -141 & -130 \\
\hline 5 & 10.0 & 8.2 & $5-a-1$ & 6.1 & 2.0 & $5-a-12$ & -174 & s.m. & n.d. & & -126 & \\
\hline 5 & & & $5-a-2$ & 4.5 & 1.2 & & & & & & & \\
\hline 5 & 10.0 & 8.4 & $5-b$ & 20.7 & 4.7 & $5-b$ & -201 & 0 & -190 & 6 & -155 & -144 \\
\hline 5 & 10.0 & 8.3 & $5-c$ & 13.0 & 3.3 & $5-c$ & -180 & s.m. & n.d. & & -133 & \\
\hline 5 & 10.0 & 8.3 & $5-d$ & 10.2 & 5.0 & 5-d & -164 & s.m. & n.d. & & -116 & \\
\hline 10 & 18.4 & 8.1 & 10-a-1 & 3.5 & 0.7 & 10-a-12 & -207 & 4 & -203 & s.m. & -162 & -157 \\
\hline 10 & & & $10-a-2$ & 2.7 & 0.7 & & & & & & & \\
\hline 10 & 18.3 & 8.1 & $10-b-1$ & 4.2 & 0.3 & $10-b-12$ & n.d. & & n.d. & & & \\
\hline 10 & & & $10-b-2$ & 3.1 & 0.2 & & & & & & & \\
\hline 10 & 18.3 & 8.1 & $10-c-1$ & 4.0 & 1.1 & $10-c-12$ & -220 & 8 & -216 & 11 & -175 & -171 \\
\hline 10 & & & $10-c-2$ & 3.1 & 1.0 & & & & & & & \\
\hline 10 & 18.4 & 8.1 & $10-d$ & 4.3 & 1.7 & $10-d$ & -197 & 9 & n.d. & & -151 & \\
\hline 15 & 25.9 & 8.1 & $15-a-1$ & 3.7 & 0.6 & 15-a-12 & -227 & 16 & -206 & s.m. & -182 & -160 \\
\hline 15 & & & $15-a-2$ & 3.0 & 0.9 & & & & & & & \\
\hline 15 & 25.9 & 8.0 & $15-b-1$ & 3.5 & 0.7 & $15-b-12$ & -207 & s.m. & n.d. & & -161 & \\
\hline 15 & & & $15-b-2$ & 2.2 & 0.3 & & & & & & & \\
\hline 15 & 25.8 & 8.1 & $15-c$ & 3.6 & 1.2 & $15-c$ & n.d. & & n.d. & & & \\
\hline 15 & 25.8 & 8.1 & $15-d-1$ & 3.0 & 0.4 & $15-d-12$ & n.d. & & n.d. & & & \\
\hline 15 & & & $15-d-2$ & 3.0 & 0.2 & & & & & & & \\
\hline
\end{tabular}


Fig. S3: $\delta \mathrm{D}$-values of plant samples grown in the laboratory experiment plotted vs. plant length. Error bars indicate standard deviation of replicate measurements. Error bars combine the standard deviation of replicate measurements and the root means square error of the A5-standard-mix $(3.96 \%$ )

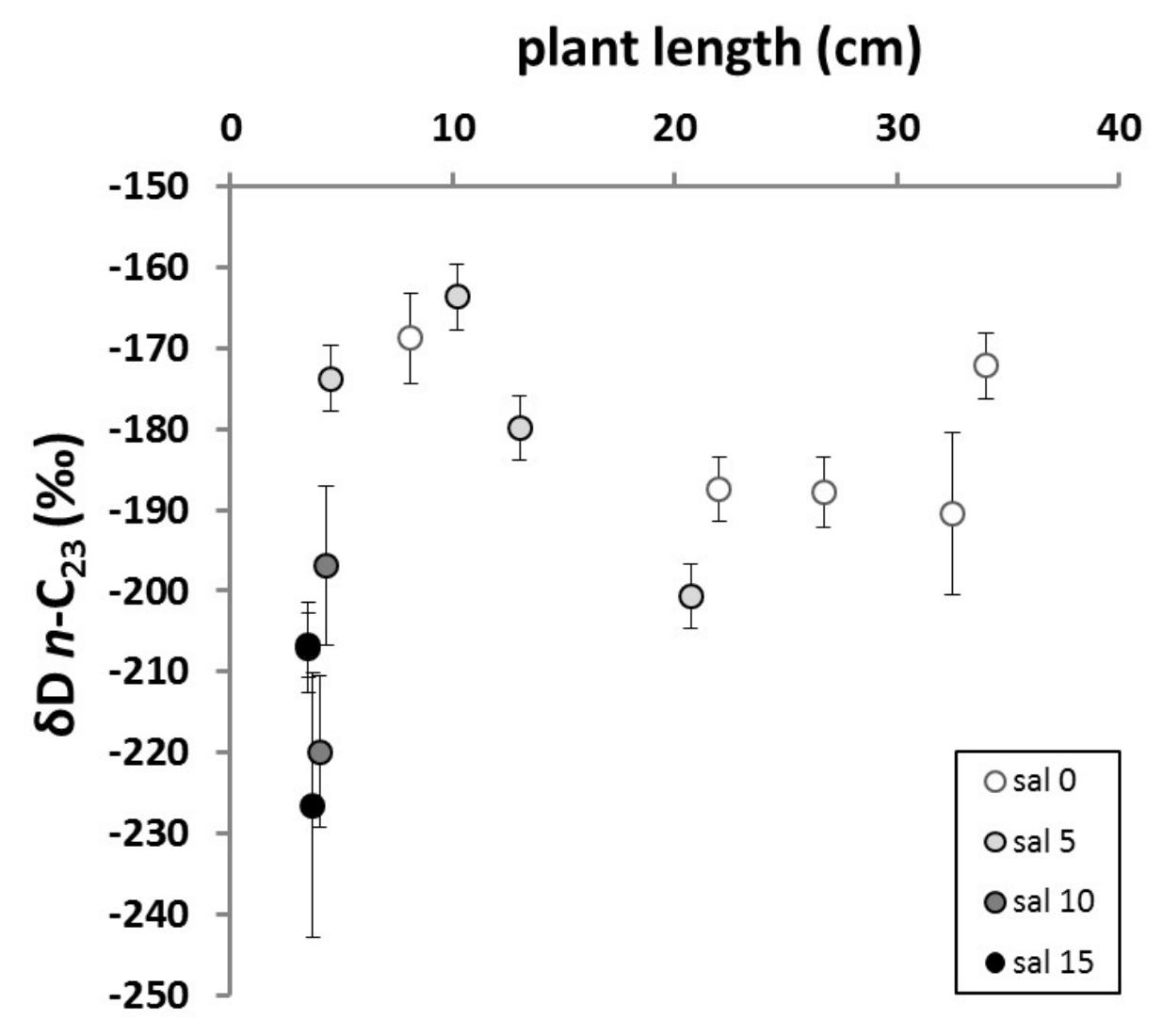

